\title{
WOMEN POLITICAL PARTICIPATION IN SOMALILAND: CHALLENGES AND OPPORTUNITIES
}

\author{
Jibril Jirde Abdi \\ Dept. Of Political and Social Science \\ Kocaeli University, Izmit, Kocaeli, Turkey
}

\begin{abstract}
Women are the most imperative in Somaliland democracy. They are the ones who take part in the political campaigns, support the candidates, and cast the most votes on Election Day but all their efforts are in vain. This study aims to examine in depth the challenges facing Somaliland's women in political involvement and the opportunities available. The study uses the primary data that has been collected through questionnaires. The study results concluded that the most respondents significantly agreed with the existence of challenges against women Political participation in Somaliland, resulting in a mean index of 3.68. The researcher has explicitly revealed four different challenges and these common challenges of women's political participation are political, cultural, religious and socio-economic challenges. On the other hand, the most respondents significantly agreed that women in Somaliland have a variety of opportunities to engage in politics, resulting in a mean index of 3.71. The study revealed that gender quota, the adoption of gender policies and regulations, and promoting women's socioeconomic status, are one of these opportunities for women to engage in politics. In this regards the study recommends that the government and all concerned institutions should move quickly to adopt policies and laws to motivate and empower women's participation in politics.
\end{abstract}

Keywords - Somaliland, Challenges, Opportunities, Participation, Politics

\section{INTRODUCTION}

The 1980s and early 1990s the world has swept by a wave of political transition or democratic change. One-party states in Africa, communist regimes in Eastern Europe and military juntas in Latin America vacated the place and replaced by governments chosen in free and fair elections. The world has experienced and eye-witnessed the downfall of the authoritarian regimes. By 1990, Sixty-five countries elected their governments in elections characterized by equitable electoral law and providing same opportunities to all (Fox, 1992).
Democracy get rid of the act of authoritarianism, dictatorship and arbitrariness and to the contrary provide a chance to engage in decision making in the political process. And Democratic system cannot successfully drive unless women are part of it. Women make up half of the population of any country. Needs of women cannot be represented by men and it was recognized the significance of women's political participation around the world. In the 1990s, although it was a good time for the democracy of the world only 11.6 percent of the World Legislatures average were women, 37 undemocratic countries women were completely absent from the legislature or nominated by men, also, 49 new democratic countries men controlled 93 percent of the parliament seats. Nevertheless, 27 long standing democratic countries provided women with a significant number of representation and chance to participate even though they occupied only 15 percent of the members of the parliament (Sinha, 2007).

In Africa, Protocol of African Women's rights in article 9 plainly stipulates equal participation women in politics and decision making without discrimination, also to be crucial actors in development of the state policies and their implementation to ensure that women are successful participant in the field of politics. The protocol positively encourages reaching equal representation of men and women; means 50 percent of each in high offices of decision making and it might bring protection of women's rights and equality of the citizens. As a result of the quota project, there has been an increase in Africa women's involvement in politics between 1995 and 2005 (Ilesanmi, 2018).

According to the Inter-Parliamentary Union, from 1995 to 2020 African women in parliaments have jumped up a distinguished number starting from 9.8 percent to o 24.4 percent. Rwanda has been leading women's parliamentary seats in the world. Women being sat more than 60 percent of the parliamentarians, as well Djibouti has made high development in the last 25 years. The overall increase of the region in women's involvement in politics diminished over the last 5 years (Druciarek, 2020). 


\section{International Journal of Engineering Applied Sciences and Technology, 2021 \\ Vol. 6, Issue 1, ISSN No. 2455-2143, Pages 106-116 \\ Published Online May 2021 in IJEAST (http://www.ijeast.com)}

In Somalia, The military regime which ruled the country for a long time, offered many opportunities for women, most important in education and economics. However, women were not participating in the decisionmaking process during that period (Mohamed, 2015). Women were forgotten during the civil war and suffered greatly. However, in the 2004 and 2008 parliaments, which comprised 275 and 550, respectively, a quota of $12 \%$ was allocated to women (Ingiriis \& Hoehne, 2013). The proportion of women increased to 24 percent seats in the 2016 elections and the advocacy groups of the international community and women activists were behind the success of the rise. Women are battling hard in the 2020 elections to get at least 30 percent and the quota project is on the table (Affi, 2020).

On the other hand, Somaliland is a self-proclaimed Republic, and its independence was declared with the help of the people on 18th May 1991 (Eubank, 2010). Women's representation in Somaliland is very weak in all fields. Somaliland has a bicameral parliament of 164 members and each council consists of 82 members. All of the members are men except a woman, Baar Saed from Sanaag region who endured men's domination in the parliamentary house, the incumbent president of Somaliland pledged to give $30 \%$ to women during the presidential election campaign, and this promise was not kept and therefore lost the hope of women in the executive branch (Gaheir \& Jama, 2018). In the case of the Somaliland judiciary, despite the fact that women serve as judges in many Muslim countries, Somaliland has chosen not to do so, and there is not a single female judge in the Somaliland judicial system. Skilled women are often assigned to other positions such as court clerks or attorneys. But not assigned as judges due to the general belief that women are unfit to serve as judges (Institute, 2016).

This study aims to examine in depth the barriers facing to Somaliland's women in political involvement or political representation, also to focus on the opportunities available to take advantage of them in order to be part of the political process and decision-making.

\section{LITERATURE REVIEW}

At the global level, low female involvement in politics has been a major source of concern. Women face a number of obstacles when it comes to participating in politics, including but not limited to the following:

\subsection{Challenges of Women Participation in Politics}

\subsubsection{Cultural challenge}

In many countries, tradition limits or restricts women's political participation by assigning them primary or minor positions as housewives, child care providers, and family workers. Normally, Traditional patriarchal ideals favour gender segregated roles, and 'traditional cultural values' work against women's empowerment, development, and participation in politics (Kassa, 2015). The traditional roles and labor divisions are distinctly gendered. This indicates that social norms prevents or make it difficult for women to leave their typically domestic roles in favor of the public roles which are outside their well-known minor traditional roles (Mlambo \& Kapingura, 2019).

Consequently, Cultural ideas about women can affect women's levels of political participation from the least role to the highest role as active politician. The misconception that originated in culture, women face discrimination because public tend to think that leadership is a masculine characteristic, so when women take the reins, they face a problem. In another sense, the public has a negative perception of women as leaders (Kunovich, Paxton, \& Hughes, 2007). Hence, women face cultural obstacles to political involvement even in countries where they have made strides in jobs or education. (Mlambo \& Kapingura, 2019), argue that Women's gender identity is mostly seen as domestic in nature, which tends to be an obstacle to their participation in formal politics. Women face a number of constraints, especially in terms of culture. The worst case scenario is that at times women appear to be their own worst enemies in terms of political progress, when they believe in outdated false perceptions including that politics being a dirty game that should be left to men (Kivoi, 2014).

\subsubsection{Religious Challenge}

Basically, religion is a source of guidance for the people to live in the universe. It creates the social structure, institutions and the social norms. It eventually has an effect on worldviews (Meyer, Rizzo, \& Ali, 1998). Thus, religion has been used to keep women out of facets of social and political life all over the world. Arguments of women's inferiority to men can be found in many of the world's major religions (Kivoi, 2014). However, the world's main religions vary in their attitudes toward women, which are either conservative or patriarchal. When it comes to Islam, it is common for Islamic law to be interpreted in a way that restricts women's activities (Kunovich, Paxton, \& Hughes, 2007). Women's social status and involvement in politics and public life can suffer as a result of wrong interpretation of the religion.

\subsubsection{Challenge in Socio-economic Terms}

Women's socioeconomic status has a greater impact on and promotes their involvement and inclusion in politics and decision-making (Mlambo \& Kapingura, 2019). Lack of economic stability and poverty deter women from participating in politics, and it is one of the most significant obstacles to women's political participation (Lakes, 2012; 


\section{International Journal of Engineering Applied Sciences and Technology, 2021 \\ Vol. 6, Issue 1, ISSN No. 2455-2143, Pages 106-116 \\ Published Online May 2021 in IJEAST (http://www.ijeast.com)}

Ullah, 2020). For instance, political campaigns are costly and need substantial financial backing to be successful (Agbalajobi, 2010). And according to various literatures, women do not have enough finance or the requisite financial backing to campaign or participate in other important aspects of the electoral process and political participation.

Women are economically dependent on men, and financial difficulties limit their political involvement, so they do not independently engage in politics (Ullah, 2018). Hence, women's low socioeconomic status puts them in tough situations, and it can also lead to them being unable to exercise their political opinions and openly choose who they vote for (Begum, 2015). As a result, the men in the family tell them who to vote for and which party to vote for. (Mlambo \& Kapingura, 2019), argue that government funding to female politicians will help them to overcome obstacles to political participation.

\subsubsection{Political Challenge}

Another barrier to women's political participation is the political challenge. (Kivoi, 2014), emphasizes that politics has been turned into a special instrument or game for men, and that men now dominate most of political parties and public bodies, also it is difficult for women to form political mobilization networks. Most of political parties promotes patriarchal ideology and are reluctant to enact changes for fear of losing political support (Mlambo \& Kapingura, 2019). Lack of coordination and collaboration between female politicians and women's organizations, as well as the structure of the electoral system, which is typically hostile to women candidates, are political obstacles that prevent women from participating in politics (Shvedova, 2005). On the other hand, Political challenges include so-called institutional constraints which mean political structures that run on rigid schedules and ignore women's issues or anything that is in the interest of women (Mlambo \& Kapingura, 2019).

\subsection{Opportunities of Women Participation in Politics}

Women's involvement in politics is essential for securing women's rightful position in society, allowing them to determine their own fate, and for the growth of true and sustainable democracy (Begum, 2015). Thus, in order women to engage in politics and play their noble role in balancing and complementing the political system, opportunities must be available to them.

Education is the path to access other opportunities that are essential for the participation in politics or in other words, it is the key that opens many important doors. For instance, women are relied on education to get high jobs that provide them with the skills and connections they need to participate in politics (Ndlovu \& Mutale, 2013). Women empowerment programs are another source of encouragement for women, as they work to dismantle cultural, conventional, and social norms that marginalize women in general (Agbalajobi, 2010).

(Ndlovu \& Mutale, 2013), stress that quotas have proven to be the most powerful short-term strategy for getting women to positions of authority and removing patriarchal frameworks that restrict women's political space and power. Moreover, economy plays an indispensable role as well. Women's political participation rises as their economy grow, so they should be given a source of income or be financially supported to increase their productivity, as well as their decision-making involvement (Nwabunkeonye, 2014).

\section{A BRIEF HISTORY OF WOMEN'S POLITICAL PARTICIPATION IN SOMALILAND}

\subsubsection{Prior Independence}

The women who once lived under the British protectorate joined the liberation movement freely, enduring all kinds of hardships. In the 1940s, women were generally involved in Struggles of independences and liberation movements. Women were active members of SYL as they joined voluntarily, they were raising funds, recruiting new members, participating in rallies, organizing the people, and hiding freedom fighters. The women went through all sorts of trauma and torture. These women in the war of independence and efforts were mostly young female and women who had been divorced, yet they did not get bored or discouraged from their role (Aidid, 2011).

Women also played an important role in building the morale and motivation of the people by composing poems and literature to express emotions, to mobilize people, to raise awareness of the dangers of colonialism, to make people understand the sweetness and goodness of freedom, and to discourage the colonists. Thus women took an active role in gaining independence and fighting for it, also they controlled and managed the families and household chores that were the backbone of life (Aidid, 2011).

In 1959 the first organization for women, the Somali Women's Association (SWA), was established. The organization worked on most of the social welfare issues where women were most vulnerable. Another movement called the Somali Women's Movement (SWM) was founded shortly after in 1960. It was a progressive women's rights movement with the goal of fighting for women's rights to overcome all the obstacles against women in political, economic, social and cultural terms. The movement was founded by women of the middle class who were committed to defending women's rights. The campaign, sadly, did not last long it was disbanded when military regime took power in 1969 (Gardner \& El Bushra, 2004). 


\section{International Journal of Engineering Applied Sciences and Technology, 2021 Vol. 6, Issue 1, ISSN No. 2455-2143, Pages 106-116 \\ Published Online May 2021 in IJEAST (http://www.ijeast.com)}

\subsubsection{Post-Independence}

Somaliland gained its independence in 1960 (Ali, 2013). And Somaliland merged with Italian Somaliland shortly after the celebration and established the first government of the new Somali Republic (Samatar \& Samatar, 2008).

During the civilian government (1960 -1969), women were not given much importance and priority. Although the constitution stated and guaranteed that women can vote and be elected, it was just a written statement, as women did not run for office practically but only they voted for male candidates (Sh. Ali, 2012).

\subsubsection{Women during Siad Barre Dictatorship}

The Siad Barre regime era, women were encouraged, provided substantial support to women and liberated from conventional barriers, and mobilized in various ways for women, such as functional women organizations, which operated throughout the country by focusing on women's development (Mohamed, 2015).

In January 1975 Siad Barre's regime passed a controversial family law. The law promoted women's rights and equated rights of men and women to inheritance and compensation, restricted men from polygamy, and empowered women in matters of marriage and divorce. In the prima facie the law was rejected by religious members in the society, who argued that the law was against Somali culture and contrary to Islam, and it originated from socialism (Massoud, 2020). In the same year, the government imprisoned the religious leaders who opposed the family law and accused them of resisting the Siad Barre regime, and ultimately the religious leaders were executed by the regime (Guudle \& Ozev, 2019).

In 1977 the Ethio-Somali war broke out, when Somalia invaded Ethiopia so as to restore the Somali region of Ethiopia which is a region inhabited by Somalis. Somali women have played a significant and unforgettable role, Somali women have been the backbone of the war and Women have held various roles and activities during the war beginning with the verbal fighting to the physical warfare (Hauwermeiren, 2012).

The women under Said Barre's regime have benefited from many things, and women accessed educational opportunities such as free compulsory basic education that facilitated women's education as well as economic opportunities, being equal to men and overcoming many obstacles, but the power of women has not changed much in terms of politics. The problem was that the military regime was not loyal to women's issues, and its measures to advance women's affairs were politically driven to eliminate its internal enemies and rivals (Mohamed, 2015).

\subsubsection{Women after the Collapse of Siad Barre Regime}

Somali women experienced many hardships during the civil war, including rape and sexual abuse. It did cause them both mental and physical harm. The same problem has led to the break-up of many families, as many women have been unable to return to their families due to fears of rape. In addition, Somali women refugees became victims of rape and sexual abuse in refugee camps and the boundaries they crossed while fleeing from the civil war (Ingiriis \& Hoehne, 2013).

Women always played their part, and that the collapse of the state and the civil war has not only affected them, but also changed their role. After they had witnessed the destruction of the war in their homes, women turned to the rebuilding of the country and launched peace efforts to bring the nation back on track (Ingiriis \& Hoehne, 2013). Moreover, women dared to meet various needs, families became financially dependent on women, took on different jobs, gained more confidence to join politics and challenge men counterparts. All in all, the Somali women during the civil war came up with types of business innovations and started to take the responsibility of their kids and the whole family (ALI \& ALI, 2013).

\subsection{The Role of Women in Peace Building and State-Building in Somaliland}

Discrimination against women in peace-building processes is not only an African issue, but a global challenge. Evidence shows that international peace mechanisms sometimes overlook and often hinder women's contributions and expressions at the international level (STONE \& MINDZIE, 2006). Eventually, women's role in peace-building and human security has been recognized internationally by the UN Security Council resolution (1325) which adopted in 2010(Rayale, 2011).

After Somaliland regained its independence from Somalia in 1991, women played a key role in peace building process, nationhood and democracy in Somaliland. For instance, during the warfare in 1992, women have had an important role, they became ambassadors between the warring clans, they did demonstrations against the war and they made possible to hold the peace conferences to encourage reconciliation. Unfortunately, the women were not given any definite role in the conferences and they were not allowed to have a significant influence for the decisions. Mostly, women were permitted to attend the conference as observers (Ridout, 2012).

In addition, Women to support their peace campaign, they composed peace poems and songs which promoting peace and coexistence. They used the poems to describe the society and how it was affected by the war. They mentioned the death of 


\section{International Journal of Engineering Applied Sciences and Technology, 2021 \\ Vol. 6, Issue 1, ISSN No. 2455-2143, Pages 106-116 \\ Published Online May 2021 in IJEAST (http://www.ijeast.com)}

male family members, and the collapse of infrastructures and social cohesion, also portrayed their vulnerable socioeconomic status to remove the conflict (Rayale, 2011).

Somali women have always been committed to promoting and building peace. One of the most the remarkable thing is that when a rift arose between the president Mohamed $\mathrm{H}$. Ibrahim Egal and some valuable traditional leaders in 2001, a group of women called 'Hargeisa Women Community' reacted by issuing a letter calling on the parties to keep the peace and not lead the country into chaos (Ingiriis \& Hoehne, 2013).

Somaliland women have changed their role in the society and become a major player in the public interest. They sacrificed and paid to save the country. Somaliland women worked individually and collectively to stop the conflict and war between the Somaliland clans in order to escape problems, displacement, refugees and death, instead encouraged the search of peace, security, harmony and coexistence to make life better and progressive.

\subsection{The Democratization Process in Somaliland and Women}

The people of Somaliland approved the country's constitution by majority vote in May 2001 (Hansen \& Bradbury, 2007). The constitution sets out many things, first and foremost the political system, equality of the citizens, women's rights and the empowerment of women in terms of participation in politics, education and the economy.

In 2002, the first multi-party system election in Somaliland was held, it was a local council election, and 23 mayors for the districts were elected (Simkin \& Paul, 2002). The most surprising was that of the 2, 760 candidates, only six candidates were women. Eventually, when the election took place just two women were elected (Gardner \& Bushra, 2004).

On 14 April 2003, almost half a million Somaliland people voted in a presidential election and elected a new president. The election took place in a nonviolent, fair and transparent manner (ICG, 2003). It was the first presidential election in Somaliland to be held under a multi-party system. A woman candidate stood as an independent candidate in this election, but was denied due to the constitution which allowed no more than three parties or independent candidates (Dualeh, 2014).

Somaliland parliamentary election (The House of Representatives) was held on 29 September 2005 and accomplished the aspirations of the country and it pushed Somaliland towards democracy (Abokor, Kibble, Bradbury, Yusuf, \& Barrett, 2006). It was the first direct parliamentary election and the elected parliamentarians took the seats from the clan-selected representatives, and it marked the end of the clan selection process and the first cycle of elections in Somaliland included the local, presidential, and parliamentary elections, all of which were held in harmony and peacefully (Hersi, 2015).

In early 2005 consultants proposed a quota for women to promote participation and representation of women in politics. The legislative committee in charge of election planned to refuse the quota consideration made by the consultants (Abokor, kibble, Bradbury, Yusuf, \& Barrett, 2006:16). Anyway, women and young people turned out in big numbers to cast the ballots. The election law mandated that each political party take the necessary steps to ensure that women candidates are included in their respective candidate lists for each region. However, on the final list of the candidates, only 7 of 246 candidates were female and finally two of them were elected as member of parliaments (Hollekim, Hansen, \& Sørensen, 2006).

The people of Somaliland elected a new president on June 26 2010. The election was deemed free and fair by both domestic and foreign observers. Following the election, there was a peaceful transition of power (Hersi, 2015). During the 2010 election campaign women activists stepped up their efforts to advocate for women's political rights by calling for the promotion the number of women in the decision making positions. Moreover, Women's support helped the Kulmiye Party win the election, which promised a $25 \%$ quota for women in all legislative branches of the government in its political manifesto (Ahmed, 2012).

On 28 November 2012 was a significant move forward in Somaliland's democratic journey, when nearly one million of Somaliland citizens went to poll and elected new local councils (375 Councilors in 19 districts). The election was monitored by domestic observers (Makokha \& Ali, 2013). Generally, 2260 candidates were formally registered to run 2012 local municipal elections and they were vying for 335 seats throughout the country. Women candidates made up just 172 which were $7.6 \%$ of the total candidates, while men candidates made up the remained $92.4 \%$. Unfortunately, in the end women obtained ten seats (Dualeh, 2014). However, from two female councilors elected in 2002 out of 379 available seats to ten woman councilors in 2012, there has been a 400 percent rise in elected female councilors (Makokha \& Ali, 2013).

Before the election, the House of Representatives was presented with a draft law on women's quota, but the motion was rejected by the majority of the members (Elder, 2013). It marked the beginning of the challenges against women in 2012 local municipal elections.

In November 2017, Somaliland held its third direct presidential election, in which people voted to elect the president. International observers found it trustworthy and credible (Pegg \& Walls, 2018). Women were influential during the campaign and they took their role in the polling 
stations and election administration. However, in Somaliland, women are generally excluded from political and elective roles. The political ambitions of women are hampered by structural obstacles and cultural constraints (Walls, Heine, Klingel, Goggin, Farag, \& Mwape, 2017).

\section{Methodology}

The study utilizes both primary and secondary data. Questionnaire is the primary data collection used by the researcher through a self-managed online survey. The researcher used literature as a reference in order to obtain the sample size. The sample size of this study was adopted from (Ahmed, 2013), the researcher examined women's political participation and decision making in Hargeisa Somaliland. This study purposively selected a sample of 169 participants by using purposive sampling. This method allows the researcher to select purposely the elements of the sample or the typical sample from the target population and his choice is of paramount importance. In other words, the researcher has the choice to select a sample that reflects or represents the whole mass (C.R.Kothari, 2004). Secondary data was used such as books, articles, journals, reports, policy and strategy papers, news sources and other documents.

\section{RESEARCH FINDINGS AND DATA ANALYSIS}

Quantitative data analysis was used in this study. Analyses were carried out with the aid of the Statistical Package for Social Sciences, (SPSS Version 20). Descriptive statistics were used to describe the data collected in research studies and to accurately characterize the variables under observation within a specific sample (Marczyk, DeMatteo,, \& Festinger, 2005). An item analysis was illustrated the strength and weaknesses based on the indicators in term of mean, standard deviation and rank. From these strengths and weaknesses, the recommendations were derived. The mean range of this study will explain below:

Table 1: Mean Standard

\begin{tabular}{|l|l|l|}
\hline No & Mean Range & Interpretation \\
\hline 1 & 1.00 up to 1.80 & Strongly Disagree \\
\hline 2 & 1.81 up to 2.60 & Disagree \\
\hline 3 & 2.61 up to 3.40 & Neutral \\
\hline 4 & 3.41 up to 4.20 & Agree \\
\hline 5 & 4.21 up to 5.00 & Strongly Agree \\
\hline
\end{tabular}

Source: Survey Data
5.1 Descriptive Statistics for the challenges of women Political participation in Somaliland

Table 2: Political Challenge

\begin{tabular}{|c|c|c|c|c|}
\hline $\mathrm{NO}$ & Items & Mean & $\begin{array}{l}\text { Std. } \\
\text { Deviation }\end{array}$ & Interpretation \\
\hline 1 & $\begin{array}{l}\text { The government } \\
\text { and political } \\
\text { parties are male } \\
\text { dominant and } \\
\text { they are not } \\
\text { willing to waive } \\
\text { their positions } \\
\text { to women. }\end{array}$ & 3.89 & 1.2661 & Agree \\
\hline 2 & $\begin{array}{l}\text { Lack of clear } \\
\text { government } \\
\text { policies and } \\
\text { laws to motivate } \\
\text { women's } \\
\text { participation in } \\
\text { politics. }\end{array}$ & 3.82 & 1.0197 & Agree \\
\hline 3 & $\begin{array}{l}\text { Women have } \\
\text { less } \\
\text { membership in } \\
\text { the political } \\
\text { parties, which } \\
\text { limits women to } \\
\text { have equal } \\
\text { opportunities in } \\
\text { candidacy for } \\
\text { the elections. }\end{array}$ & 3.98 & 1.0059 & Agree \\
\hline 4 & $\begin{array}{c}\text { Women's } \\
\text { organizations } \\
\text { failed to } \\
\text { politically } \\
\text { empower and to } \\
\text { build up } \\
\text { linkages among } \\
\text { women } \\
\end{array}$ & 3.59 & 1.0933 & Agree \\
\hline 5 & $\begin{array}{l}\text { Women's voice } \\
\text { is unheard, } \\
\text { since their } \\
\text { representation } \\
\text { in the political } \\
\text { arena is too } \\
\text { limited. }\end{array}$ & 3.80 & 1.1916 & Agree \\
\hline 6 & $\begin{array}{l}\text { Lack of political } \\
\text { ambition of } \\
\text { women } \\
\text { contributed to } \\
\text { their low } \\
\text { participation in } \\
\text { politics. }\end{array}$ & 3.33 & 1.1490 & Neutral \\
\hline
\end{tabular}




Overall Mean $3.740|l|$ Agree
Source: Survey data
As Table 2 shows that the most of the respondents
agreed the existence of political challenges with the overall
mean of 3.74. The political challenges include lack of policies
and regulations that allow women to engage in politics or that
favour women in particular. Additionally, men dominate the
government and political parties, limiting women's
opportunities, and also women's organisations which do not
meet their mandates as intended or offer practical assistance to
women.

Table 3: Religious challenge

\begin{tabular}{|c|c|c|c|c|}
\hline No & Items & Mean & $\begin{array}{c}\text { Std. } \\
\text { Deviation }\end{array}$ & Interpretation \\
\hline 1 & $\begin{array}{c}\text { Basically Islamic } \\
\text { religion proposes } \\
\text { women to carry } \\
\text { out the essential } \\
\text { work of their } \\
\text { home. }\end{array}$ & 3.73 & 1.251 & Agree \\
\hline 2 & $\begin{array}{c}\text { Religious } \\
\text { misperceptions } \\
\text { resulted women } \\
\text { not to participate } \\
\text { actively in the } \\
\text { politics }\end{array}$ & 3.38 & 1.313 & Neutral \\
\hline 3 & $\begin{array}{c}\text { Islamic scholars } \\
\text { differ on the } \\
\text { appropriate level } \\
\text { of women's } \\
\text { participation in } \\
\text { political } \\
\text { activities. }\end{array}$ & 3.37 & 1.056 & Neutral \\
\hline $\begin{array}{c}\text { Overall Mean } \\
\text { Index }\end{array}$ & 3.49 & & Agree \\
\hline
\end{tabular}

Source: Survey data

Respondents were asked three questions regarding religious challenges in order to achieve the goal of the study and they revealed that in Somaliland, a religious challenge prohibits women from participating in politics. The religious obstacles, according to the study, are religious misperception or a lack of a broad understanding of religion.

Table 4: Socio-economic Challenge

\begin{tabular}{|l|l|l|l|l|}
\hline No & Items & Mean & $\begin{array}{l}\text { Std. } \\
\text { Deviations }\end{array}$ & Interpretations \\
\hline 1 & $\begin{array}{c}\text { Practically } \\
\text { most society } \\
\text { does not prefer } \\
\text { women to } \\
\text { represent in } \\
\text { the political }\end{array}$ & 3.85 & 1.139 & Agree \\
\hline
\end{tabular}

\begin{tabular}{|c|c|c|c|c|}
\hline & arena. & & & \\
\hline 2 & $\begin{array}{l}\text { Majority of } \\
\text { women do not } \\
\text { have the } \\
\text { financial } \\
\text { resources to } \\
\text { take part in the } \\
\text { electoral } \\
\text { processes of } \\
\text { the country. }\end{array}$ & 3.69 & 1.259 & Agree \\
\hline 3 & $\begin{array}{l}\text { Women have } \\
\text { no power to } \\
\text { participate in } \\
\text { the politics of } \\
\text { the country, } \\
\text { due to the } \\
\text { Educational } \\
\text { barriers }\end{array}$ & 2.61 & 1.268 & Neutral \\
\hline \multirow[t]{2}{*}{4} & $\begin{array}{c}\text { Women } \\
\text { themselves do } \\
\text { not support } \\
\text { and promote } \\
\text { one another in } \\
\text { terms of } \\
\text { voting and } \\
\text { finance }\end{array}$ & 3.99 & 1.185 & Agree \\
\hline & $\begin{array}{l}\text { Overall Mean } \\
\text { Index }\end{array}$ & 3.53 & & \\
\hline
\end{tabular}

Four questions were posed to the participants in order to identify the existence of socio-economic challenges, and they all revealed, as mentioned in the study (3.53), that women in Somaliland face socio-economic challenges to engage in politics effectively and actively. These impediments stand in the way of women's political aspiration and creativity. The socio-economic challenges include the fact that politically, women do not empower and help one another, and they do not receive practical support from society in terms of politics. Once more, the vast majority of women lack the financial means to participate in the electoral and democratic processes of the country.

Table 5: Traditional Challenge

\begin{tabular}{|c|c|c|c|c|}
\hline No & Items & Mean & $\begin{array}{l}\text { Std. } \\
\text { Deviation }\end{array}$ & Interpretations \\
\hline 1 & $\begin{array}{l}\text { Somali tradition } \\
\text { is not } \\
\text { recognized } \\
\text { Women's equal } \\
\text { access to } \\
\text { political } \\
\text { participation } \\
\text { with men. }\end{array}$ & 4.21 & 1.019 & $\begin{array}{l}\text { Strongly } \\
\text { Agree }\end{array}$ \\
\hline
\end{tabular}


International Journal of Engineering Applied Sciences and Technology, 2021

Vol. 6, Issue 1, ISSN No. 2455-2143, Pages 106-116

Published Online May 2021 in IJEAST (http://www.ijeast.com)

\begin{tabular}{|c|c|c|c|c|c|c|c|c|c|}
\hline \multirow[t]{2}{*}{2} & \multirow{2}{*}{$\begin{array}{l}\text { The elders of } \\
\text { the clan are not } \\
\text { willing that } \\
\text { women have } \\
\text { the power to } \\
\text { serve and } \\
\text { represent their } \\
\text { clan in political } \\
\text { roles. }\end{array}$} & \multirow[t]{2}{*}{4.07} & \multirow[t]{2}{*}{1.013} & \multirow[t]{2}{*}{ Agree } & & $\begin{array}{l}\text { role in the } \\
\text { political } \\
\text { participation. }\end{array}$ & & & \\
\hline & & & & & \multirow[t]{2}{*}{2} & \multirow{2}{*}{$\begin{array}{l}\text { Women can } \\
\text { be } \\
\text { empowered } \\
\text { by the } \\
\text { adaption of } \\
\text { gender } \\
\text { policies and } \\
\text { regulation that } \\
\text { eradicates } \\
\text { long-lasting } \\
\text { bad practices. }\end{array}$} & \multirow[t]{2}{*}{3.53} & \multirow[t]{2}{*}{.9942} & \multirow[t]{2}{*}{ Agree } \\
\hline \multirow[t]{2}{*}{3} & \multirow{2}{*}{$\begin{array}{c}\text { Female } \\
\text { candidates are } \\
\text { not supported } \\
\text { by women } \\
\text { voters; instead, } \\
\text { they prefer to } \\
\text { vote for a man } \\
\text { who belongs to } \\
\text { their birth clan. }\end{array}$} & \multirow[t]{2}{*}{4.06} & \multirow[t]{2}{*}{1.084} & \multirow[t]{2}{*}{ Agree } & & & & & \\
\hline & & & & & \multirow[t]{2}{*}{3} & \multirow{2}{*}{$\begin{array}{l}\text { Gender quota } \\
\text { is a good } \\
\text { manner to } \\
\text { increase } \\
\text { women's } \\
\text { participation } \\
\text { in politics. }\end{array}$} & \multirow[t]{2}{*}{3.69} & \multirow[t]{2}{*}{1.190} & \multirow[t]{2}{*}{ Agree } \\
\hline \multirow[t]{4}{*}{4} & \multirow{2}{*}{$\begin{array}{l}\text { The father } \\
\text { lineage is a } \\
\text { cultural factor } \\
\text { that provides } \\
\text { the context } \\
\text { upon which } \\
\text { women play } \\
\text { and accept } \\
\text { minor roles. }\end{array}$} & \multirow[t]{2}{*}{3.52} & \multirow[t]{2}{*}{.9946} & \multirow[t]{2}{*}{ Agree } & & & & & \\
\hline & & & & & \multirow[t]{2}{*}{4} & \multirow[t]{2}{*}{$\begin{array}{l}\text { Educated } \\
\text { women have } \\
\text { shown that } \\
\text { they have the } \\
\text { will and the } \\
\text { capacity for } \\
\text { leadership. }\end{array}$} & \multirow[t]{2}{*}{4.12} & \multirow[t]{2}{*}{.9500} & \multirow[t]{2}{*}{ Agree } \\
\hline & \multirow{2}{*}{$\begin{array}{l}\text { Overall Mean } \\
\text { Index }\end{array}$} & \multirow[t]{2}{*}{3.97} & & & & & & & \\
\hline & & & & & \multirow[t]{2}{*}{5} & \multirow[b]{2}{*}{$\begin{array}{l}\text { Advocacy and } \\
\text { lobbying are } \\
\text { one of the } \\
\text { tools that can } \\
\text { be } \\
\text { empowered } \\
\text { women's } \\
\text { participation } \\
\text { in politics. }\end{array}$} & \multirow[t]{2}{*}{3.78} & \multirow[t]{2}{*}{.9681} & \multirow[t]{2}{*}{ Agree } \\
\hline & $\begin{array}{l}\text { In terms of cl } \\
\text { nges. In order } \\
\text { n, four questions } \\
\text { d with the high } \\
\text { st barrier to } \\
\text { liland is the tr }\end{array}$ & $\begin{array}{l} \\
\text { allenge } \\
\text { o attai } \\
\text { were a } \\
\text { st mea } \\
\text { womer } \\
\text { ditiona }\end{array}$ & $\begin{array}{l}\text { the last part } \\
\text { the result ar } \\
\text { ed to the res } \\
\text { of } 3.97 \text {. It i } \\
\text { political } \\
\text { challenge. A }\end{array}$ & $\begin{array}{l}\text { s the traditional } \\
\text { depth of this } \\
\text { ondents and all } \\
\text { dicates that the } \\
\text { nvolvement in } \\
\text { shown in the }\end{array}$ & & & & & \\
\hline & $\begin{array}{l}\text { iptive analysis o } \\
\text { snize women's eq } \\
\text { and also, the el } \\
\text { en have the pow } \\
\text { ions. Aside from } \\
\text { olays a great role } \\
\text { litical participatio }\end{array}$ & $\begin{array}{l}\text { this } \\
\text { tal acce } \\
\text { lers of } \\
\text { er to } r \\
\text { that, th } \\
\text { in wom } \\
\text { l. }\end{array}$ & $\begin{array}{l}\text { ly, Somali tr } \\
\text { to political } \\
\text { e clans are } \\
\text { resent their } \\
\text { father lineag } \\
\text { 's poor perf }\end{array}$ & $\begin{array}{l}\text { dition does not } \\
\text { articipation with } \\
\text { tot willing that } \\
\text { lan in political } \\
\text { culture matters } \\
\text { mance in terms }\end{array}$ & 6 & $\begin{array}{l}\text { The increase } \\
\text { of women's } \\
\text { socio- } \\
\text { economic } \\
\text { status } \\
\text { enhances their } \\
\text { participation } \\
\text { in Politics. }\end{array}$ & 3.89 & .9724 & Agree \\
\hline & $\begin{array}{l}\text { Descriptive Stati } \\
\text { ical participation i }\end{array}$ & $\begin{array}{l}\text { tics fo } \\
\text { Soma }\end{array}$ & $\begin{array}{l}\text { the opportun } \\
\text { and }\end{array}$ & ties of women & 7 & $\begin{array}{l}\text { The } \\
\text { government } \\
\text { recognizes }\end{array}$ & 3.15 & 1.195 & Neutral \\
\hline & 6: Opportunities & of wom & 's participati & $\mathrm{n}$ in Politics & & and respects & & & \\
\hline $\mathrm{No}$ & Items & Mean & $\begin{array}{l}\text { Std. } \\
\text { Deviation }\end{array}$ & Interpretations & & $\begin{array}{l}\text { the } \\
\text { international }\end{array}$ & & & \\
\hline 1 & $\begin{array}{l}\text { Democratic } \\
\text { principles } \\
\text { give women a }\end{array}$ & 3.84 & .9533 & Agree & & $\begin{array}{l}\text { obligations } \\
\text { that promote } \\
\text { the women's }\end{array}$ & & & \\
\hline
\end{tabular}




\begin{tabular}{|c|c|c|c|c|}
\hline & $\begin{array}{c}\text { political } \\
\text { participation. }\end{array}$ & & & \\
\hline 8 & $\begin{array}{l}\text { The pressure } \\
\text { of the Civil } \\
\text { Society and } \\
\text { international } \\
\text { community } \\
\text { promotes } \\
\text { women's } \\
\text { political } \\
\text { participation. }\end{array}$ & 3.69 & 1.103 & Agree \\
\hline & $\begin{array}{l}\text { Overall Mean } \\
\text { Index }\end{array}$ & 3.71 & & Agree \\
\hline
\end{tabular}

Source: Survey data

Results in table 6 indicate that Participants decided and agreed on the questions posed with an overall mean of 3.71, which means that women in Somaliland have opportunities to participate in politics. In the context of this study, women in Somaliland have a variety of opportunities to engage in politics, as seen in the study. These opportunities include:

Gender quota is one of these opportunities for women to engage in politics and to take their vital political role, and according to the study, gender quota is a necessary component of women's participation in politics. Following that education is very crucial always and particularly here, because educated women have shown that they have the desire and potential for leadership, which increases their chances of actively and successfully participating in higher levels of decision-making and politics.

Furthermore, as women's socio-economic status rises, so does their political participation; lobbying and advocacy are two of the most effective methods for empowering women's political participation. As mentioned in the analysis of this study, the efforts of Somaliland civil society organizations and the international community are worth mentioning because they play an important role in this issue, and need to be sustained. Finally, and most significantly, long-standing traditional and bad practices can be eliminated by the adoption of gender policies and regulations, which removes one of the main barriers to women achieving their political aspiration.

\section{MAJOR FINDINGS OF THE STUDY}

The first objective of the research was to study and investigate the major challenges against women Political participation in Somaliland. To reach this objective, they were divided into four main parts, each with its own set of questions and the participants agreed that there are challenges in Somaliland that prevent women from participating in politics and these challenges of women's political participation are political, cultural, religious and socio-economic challenges.
The second objective of the research was to identify the opportunities for Somaliland women to participate in politics. In order to achieve this aim eight questions were asked to the participants to discover their attitude toward this objective and most of the participants agreed that women in Somaliland have a variety of opportunities to engage in politics. The study revealed that gender quota, the adoption of gender policies and regulations, and promoting women's socio-economic status, are one of these opportunities for women to engage in politics

\section{CONCLUSION}

The aim of this study is to examine the challenges and opportunities for women to participate in politics in Somaliland. To identify the challenges and opportunities of women's political participation in Somaliland, data was collected and analyses were conducted.

The study shows that most of the participants accepted and agreed on the existence of challenges against women Political participation in Somaliland, resulting in a mean index of 3.68. On the other hand, the study results concluded that the most respondents significantly agreed with the opportunities of women to participate in politics in Somaliland, resulting in a mean index of 3.71 .

\section{RECOMMENDATIONS}

- The government and all concerned institutions should move quickly to adopt policies and laws to motivate and empower women's participation in politics.

- Religious leaders should dispel any misconceptions that might prevent women from actively participating in politics. They should also inform and clarify the public about the noble position that religion has bestowed upon women, their place in society, and their role in political participation.

- In terms of political participation, traditional elders must play a supporting role promoting women to put an end to women's unequal access to political participation compared to men.

- Majority of women do not have the financial means to take part in the electoral processes of the country, they should be financially supported.

- Women's education is critical for both the nation's growth and their involvement in politics; thus, women should be educated so that they can support the country and engage in its political affairs.

- The study highly advised, women to be part the formation and being membership of political 


\section{International Journal of Engineering Applied Sciences and Technology, 2021 \\ Vol. 6, Issue 1, ISSN No. 2455-2143, Pages 106-116 \\ Published Online May 2021 in IJEAST (http://www.ijeast.com)}

parties, on the other hand women should support and promote one another in terms of voting and financing one another.

\section{REFERENCES}

[1] Abdi, C. M. (2007). Convergence of civil war and the religious right: Reimagining Somali women. Signs: Journal of Women in Culture and Society, 183-207.

[2] Abokor, A. Y., kibble, S., Bradbury, M., Yusuf, H. A., \& Barrett, G. (2006). Further steps to democracy: The Somaliland parliamentary elections, September 2005. London: Progressio.

[3] Abukar, A. (2015). Somalia: A brief country report. Association of European Parliamentarians with Africa.

[4] Affi, L. (2020). Excluding women: the clanization of Somali political institutions. Bergen: CMI (Chr. Michelsen Institute).

[5] Agbalajobi, D. (2010). Womens participation and the political process in Nigeria: Problems and prospects. African Journal of Political Science and International Relations, 4(2), , 75-82.

[6] Yusuf, H. A. (2012). The Saga of the Pursuit of Women's Quota in Somaliland. Hargeisa: Social Research \& Development Institute.

[7] Aidid, S. (2011). Haweenku Wa Garab (Women are a Force): Women and the Somali Nationalist Movement, 1943-1960. Bildhaan: An International Journal of Somali Studies, 103-124.

[8] ALI, D. A., \& ALI, A. Y. (2013). Challenges and constraints faced by Somali women entrepreneurs in Benadir region. Interdisciplinary Journal of Contemporary Research in Business, 436-441.

[9] Ali, N. M. (2013). Searching for an Identity: Examining the Somaliland Quest for Recognition. Asian Journal of Humanities and Social Studies, 337-344.

[10] Begum, S. (2015). Political participation of women: Some issues and challenges. International Journal of Applied Research, 480-486.

[11] C.R.Kothari. (2004:59). Research Methodology: Methods and Techniques. New Delhi: New Age International (P) Ltd.

[12] Druciarek, M. (2020). Women in parliament:1995-2020. Inter-Parliamentary Union.

[13] Dualeh, A. M. (2014). Republic of Somaliland Ministry of Labor and Social Affairs (Somaliland Post Election Study). Republic of Somaliland Ministry of Labor and Social Affairs.

[14] Elder, C. (2013). What future for democracy in Somaliland? Nairobi: RVI.
[15] Eubank, N. (2010). Peace-Building without External Assistance: Lessons from Somaliland. Center for Global Development Working Paper, 5.

[16] Fox, G. H. (1992:540). The right to political participation in international law. Yale J. Int'l L.

[17] Gardner, J., \& Bushra, J. E. (2004). Somalia-the untold story: the war through the eyes of Somali women. CIIR: Plutor Press.

[18] Gardner, J., \& Warsame, A. M. (2004). Women, Clan Identity and Peace-building. J. Gardner, \& J. El Bushra içinde, Somalia-The Untold Story: The War Through the Eyes of Somali Women. London: Pluto Press.

[19] Guudle, M. O., \& Ozev, M. H. (2019). Somali State Conflict: Revisiting the Political Economy of the Somali Security State (1969-1991). Ortadoğu Etütleri, 206-233.

[20] Hansen, S. J., \& Bradbury, M. (2007). Somaliland: a new democracy in the Horn of Africa. Review of African Political Economy, 461-476.

[21] Hauwermeiren, R. V. (2012). The Ogaden War: Somali women's roles. Afrika focus, 9-30.

[22] Hersi, M. F. (2015). Confronting the Future of Somaliland's Democracy: Lessons from a Decade of Multi-partyism and the Way Forward.

[23] Hollekim, R., Hansen, S. J., \& Sørensen, G. M. (2006). Somaliland: Elections for the Lower House of Parliament September 2005. NORDEM.

[24] ICG. (2003). Somaliland: Democratisation and Its Discontents. Nairobi/Brussels: International Crisis Group.

[25] Ilesanmi, O. O. (2018). Women's Visibility in Decision Making Processes in Africa-Progress, Challenges, and Way Forward. Frontiers in Sociology, 4.

[26] Ingiriis, M. H., \& Hoehne, M. V. (2013). The impact of civil war and state collapse on the roles of Somali women: a blessing in disguise. Journal of Eastern African Studies, , 314-333.

[27] Institute, H. (2016). The State of the Judiciary in Somaliland. Horizon Institute.

[28] Kassa, S. (2015). Challenges and Opportunities of Women Political Participation in Ethiopia. Journal of Global economics, 3(4), , 1-7.

[29] Kivoi, D. L. (2014). Factors impeding political participation and representation of women in Kenya. Humanities and Social Sciences, 173-181.

[30] Kunovich, S. L., Paxton, P., \& Hughes, M. M. (2007). Gender in Politics. The Annual Review of Sociology.

[31] Makokha, J., \& Ali, Y. (2013). Somalilanders speak Lessons from the November 2012 local elections.

[32] Gaheir, M. \& Jama, G. (2018). Somaliland: A Male Democracy. Hargeisa: Center for Policy Analysis (CPA).

[33] Massoud, M. F. (2020). The Rule of Law in Fragile States: Dictatorship, Collapse, and the Politics of Religion 
in Post-Colonial Somalia. Journal of Law and Society, S111-S125.

[34] Meyer, K., Rizzo, H., \& Ali, Y. (1998). Islam and the Extension of Citizenship Rights to Women in Kuwait. Journal for the Scientific Study of Religion, 131-144 